\title{
Phenoxazine Based Units- Synthesis, Photophysics and Electrochemistry
}

\author{
Anna Nowakowska-Oleksy • Jadwiga Soloducho • \\ Joanna Cabaj
}

Received: 14 April 2010 /Accepted: 22 June 2010 /Published online: 13 July 2010

(C) The Author(s) 2010. This article is published with open access at Springerlink.com

\begin{abstract}
A few new phenoxazine-based conjugated monomers were synthesized, characterized, and successfully used as semiconducting materials. The phenoxazine-based oligomers have low ionization potentials or high-lying HOMO levels $(\sim 4.7 \mathrm{eV})$, which were estimated from cyclic voltammetry. Conjugated oligomers offer good filmforming, mechanical and optical properties connected with their wide application. These results demonstrate that phenoxazine-based conjugated mers are a promising type of semiconducting and luminescent structures able to be used as thin films in organic electronics.
\end{abstract}

Keywords Phenoxazines · Stille condensation · Cyclic voltammetry $\cdot$ Conductivity $\cdot$ Luminescence $\cdot$ Atomic Force Microscopy (AFM)

\section{Introduction}

Conjugated organic semiconductors that have high charge carrier mobilities, solution process ability, and air stability are of enormous interest for applications in organic electronics, particularly thin film transistors [1-3], photovoltaic cells [4-7], electrochromic materials $[8,9]$, and light-emitting devices [10].

Phenoxazines usually have high luminescence quantum yields and are known as efficient laser dyes, are also

\footnotetext{
A. Nowakowska-Oleksy $\cdot$ J. Sołoducho $(\bowtie) \cdot J$. Cabaj

Faculty of Chemistry, Wrocław University of Technology,

Wybrzeże Wyspiańskiego 27,

50-370 Wrocław, Poland

e-mail: jadwiga.soloducho@pwr.wroc.pl
}

scarcely explored as building blocks in current OLED materials [11]. Several 1,4-benzoxazino[2,3-b]phenoxazines have been prepared and used as hole-injection materials in emitting materials [12]. Conjugated copolymers built of derivatives of phenoxazine and dialkylfluorene are well-known as semiconducting field effect transistors as well as electroluminescent tools [13, 14]. Despite the fact, compared to carbazoles, phenothiazines $[15,16]$, phenoxazine has attracted even much less attention as a building block in organic semiconductors [14]. However, phenoxazine-based donor-acceptor molecules have not yet been studied frequently. Furthermore, the chemical structure of phenoxazine resembles that of triphenylamine, which is widely used as a holetransporting organic material. Thus, polymers/oligomers containing a phenoxazine unit could be promising conducting and fluorescent materials $[17,18]$.

The reason for this scarcity of polymer semiconductors for developing novel systems for electronic and optoelectronic devices is that the materials must meet many requirements. Most notably good $\pi$-electron delocalization along the chain and a high degree of intermolecular order, good intermolecular $\pi$-stacking and ordered supramolecular morphology, and sufficiently low ionization potential (IP) is demanded.

In this paper, continuing our concerns connected with electrochemistry of heterocyclic block structures [19], we report a previous study exploring the fused tricyclic phenoxazine ring as a building block for the construction of semiconducting and luminescent materials for electronic devices. A few new phenoxazine-containing $\pi$-conjugated mers, with the structure shown in Fig. 1, were synthesized and investigated. 


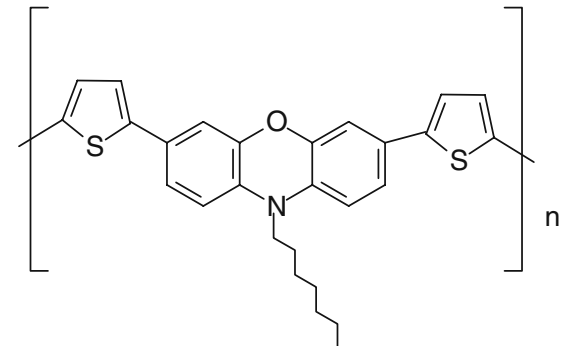

Fig. 1 Structure of poly [ $N$-alkyl-bis(2-thiophene)phenoxazine]

\section{Experimental}

Materials and instruments

${ }^{1} \mathrm{H}-\mathrm{NMR}$ and ${ }^{13} \mathrm{C}$-NMR spectra were recorded using a Bruker 300 spectrometer. Chemical shifts are denoted (internal TMS $=0.0 \mathrm{ppm}$ ). Preparative column chromatography (CC) was carried out on glass columns of different sizes packed with silica gel Merck $60(40-63 \mu \mathrm{m})$. MS spectra were taken on a Bruker micrOTOF-Q, FWHM$17500,20 \mathrm{~Hz}$. Phenoxazine, 1-bromobutane, 1bromononane, 1-bromohexadecane, sodium hydride $(60 \%$ in mineral oil), 2-(-tributylstannyl)thiophene and 2-(tributylstannyl)furane were obtained from Aldrich and use as received. Tetrakis(triphenyl)phosphine palladium and 2(-tributylstannyl)pyridine were obtained from Lancaster and used as received. Anhydrous THF was purified by vacuum distillation before use.

Syntheses

\section{3,7-Dibromo-N-alkylphenoxazine (1b-c)}

3,7-Dibromo- $N$-alkylphenoxazines was synthesized according modified earlier procedures [13, 20-23] typical for alkylation's reactions.

Selected data for 3,7-dibromo-N-hexadecylphenoxazine 1c $\mathrm{Y}=41 \%(2.07 \mathrm{~g})$, greenish crystals, mp. $65-66^{\circ} \mathrm{C},{ }^{1} \mathrm{H}$ NMR $\left(\mathrm{CDCl}_{3}\right) \delta: 6.86(\mathrm{dd}, J=2.21 \mathrm{~Hz}, J=2.21 \mathrm{~Hz}, 2 \mathrm{H}$, arom. H), 6.70 (d, $J=2.18 \mathrm{~Hz}, 2 \mathrm{H}$, arom. H), $6.26(\mathrm{~s}, 2 \mathrm{H}$, arom. $\mathrm{H}), 3.41-3.36\left(\mathrm{~m}, 2 \mathrm{H}, \mathrm{CH}_{2}\right), 1.57-1.54\left(\mathrm{~m}, 2 \mathrm{H}, \mathrm{CH}_{2}\right)$, $1.34-1.15\left(\mathrm{~m}, 26 \mathrm{H}, \mathrm{CH}_{2}\right), 0.87\left(\mathrm{t}, J=6.62 \mathrm{~Hz}, 3 \mathrm{H}, \mathrm{CH}_{3}\right) .{ }^{13} \mathrm{C}$ NMR $\left(\mathrm{CDCl}_{3}\right) \delta: 145.15,132.13,126.49,118.51,112.35$, $112.14,44.22,34.02,32.83,31.91,29.65,29.54,29.42$, 29.34, 28.76, 28.16, 26.80, 24.63, 22.67, 14.11.Anal. Calc. for $\mathrm{C}_{28} \mathrm{H}_{39} \mathrm{Br}_{2} \mathrm{NO}$ : C, 59.49; H, 6.91; Br, 28.29; N, 2.48; O, 2.83. FTMS-ESI (m/z): $\left[\mathrm{M}^{+}\right]$calc. for $\mathrm{C}_{28} \mathrm{H}_{39} \mathrm{Br}_{2} \mathrm{NO}, 565.01$.

\section{3,7-Bis(2-thiophene)-N-alkylphenoxazine (2a-c)}

3,7-Bis(2-thiophene)-N-alkylphenoxazine (2a-c) Monomer (2) was synthesized according to our previous experience $[22,23]$ by a coupling reaction of 3,7-dibromo- $N$-alkylphenoxazine 1 ( $3.53 \mathrm{mmole})$ with 2-(-tributylstannyl)thiophene (8.11 mmole), and tetrakis(triphenylphosphine)palladium (0) $(0.40 \mathrm{mmol})$ as catalyst. The mixture was stirred at $100^{\circ}$ $\mathrm{C}$ for $72 \mathrm{~h}$ under nitrogen. The reaction was then quenched by addition of $40 \mathrm{ml}$ of water, than the water solution was extracted with chloroform. Organic phase was washed with water, dried, and the solvent was removed by rotary evaporator. The crude product was purified by column chromatography (hexane: ethyl acetate, 1:1).

Selected data for 3,7-bis(2-thiophene)-N-butylphenoxazine 2a $\mathrm{Y}=50 \%(0.2 \mathrm{~g})$, yellowish oil, ${ }^{1} \mathrm{H}$ NMR $\left(\mathrm{CDCl}_{3}\right) \delta$ : 7.69-7.63 (m, 2H, arom. H), $7.46(\mathrm{~d}, J=7.56 \mathrm{~Hz}, 2 \mathrm{H}$, arom. H), 7.16 (d, $J=4.17 \mathrm{~Hz}, 2 \mathrm{H}$, arom. H), 7.00 (d, $J=3.54 \mathrm{~Hz}$, $2 \mathrm{H}$, arom. H), 6.78 (d, J=5.34 Hz, 2H, arom. H), 6.48 (s, $2 \mathrm{H}$, arom. H), 3.52-3.46 (m, 2H, $\left.\mathrm{CH}_{2}\right), 1.65-1.55(\mathrm{~m}, 2 \mathrm{H}$, $\left.\mathrm{CH}_{2}\right), 1.46-1.33\left(\mathrm{~m}, 2 \mathrm{H}, \mathrm{CH}_{2}\right), 0.96(\mathrm{t}, J=7.28 \mathrm{~Hz}, 3 \mathrm{H}$,

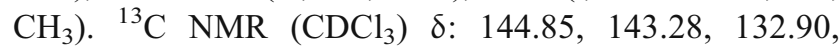
$132.12,131.99,131.48,129.08,128.97,128.58,128.42$, $127.90,123.90,122.06,121.25,118.23,118.06,112.94$, 111.92, 111.21, 111.01, 43.87, 30.15, 20.08, 13.83. Anal. Calc. for $\mathrm{C}_{24} \mathrm{H}_{21} \mathrm{NOS}_{2}$ : C, 72.18; H, 5.26; N, 3.51; O, 3.01; $\mathrm{S}, 16.04$. FTMS-ESI $(\mathrm{m} / \mathrm{z}):\left[\mathrm{M}^{+}\right]$calc. for $\mathrm{C}_{24} \mathrm{H}_{21} \mathrm{NOS}_{2}$, 399.21 .

Selected data for 3,7-bis(2-thiophene)-N-nonylphenoxazine 2b Y $=55 \%(0.22 \mathrm{~g})$, yellow oil, ${ }^{1} \mathrm{H}$ NMR $\left(\mathrm{CDCl}_{3}\right) \delta: 7.72$ $7.65(\mathrm{~m}, 1 \mathrm{H}$, arom. H), 7.53-7.46 (m, 2H, arom. H), 7.18 $7.12(\mathrm{~m}, 3 \mathrm{H}$, arom. H), 7.05-6.99 (m, 2H, arom. H), 6.84 (s, $1 \mathrm{H}$, arom. H), 6.75 (d, $J=11.78 \mathrm{~Hz}, 1 \mathrm{H}$, arom. H), 6.51$6.45\left(\mathrm{~m}, 2 \mathrm{H}\right.$, arom. H), 3.50-3.45 (m, 2H, $\left.\mathrm{CH}_{2}\right), 1.66-1.61$ $\left(\mathrm{m}, 3 \mathrm{H}, \mathrm{CH}_{2}\right), 1.38-1.27\left(\mathrm{~m}, 11 \mathrm{H}, \mathrm{CH}_{2}\right), 0.88(\mathrm{t}, J=$ $\left.9.09 \mathrm{~Hz}, 3 \mathrm{H}, \mathrm{CH}_{3}\right) .{ }^{13} \mathrm{C} \mathrm{NMR}\left(\mathrm{CDCl}_{3}\right) \delta: 144.88,143.31$, $136.47,132.07,131.93,131.43,129.04,128.91,128.58$, $128.35,127.90,123.87,122.04,121.24,118.18,118.01$, 112.94, 111.90, 111.23, 111.04, 44.19, 31.79, 27.83, 27.10, 26.85, 24.91, 22.61, 14.06, 13.56. Anal. Calc. for $\mathrm{C}_{29} \mathrm{H}_{31} \mathrm{NOS}_{2}$ : C, 73.58; H, 6.55; N, 2.96; O, 3.38; S, 13.53. FTMS-ESI $(\mathrm{m} / \mathrm{z})$ : $\left[\mathrm{M}^{+}\right]$calc. for $\mathrm{C}_{29} \mathrm{H}_{31} \mathrm{NOS}_{2}$, 473.21 .

Selected data for 3,7-bis(2-thiophene)-N-hexadecylphenoxazine $2 \mathrm{c} \mathrm{Y}=60 \%(0.42 \mathrm{~g})$, greenish crystals, $\mathrm{mp} .69-70^{\circ} \mathrm{C}$, ${ }^{1} \mathrm{H}$ NMR $\left(\mathrm{CDCl}_{3}\right)$ 8: 7.69-7.63 (m, 2H, arom. H), $7.46(\mathrm{~d}$, $J=6.85 \mathrm{~Hz}, 2 \mathrm{H}$, arom. H), $7.17(\mathrm{~d}, J=4.94 \mathrm{~Hz}, 2 \mathrm{H}$, arom. H), $7.01(\mathrm{~d}, J=3.74 \mathrm{~Hz}, 2 \mathrm{H}$, arom. H), 6.89-6.81 (m, $2 \mathrm{H}$, 
arom. H), 6.47 (s, 2H, arom. H), 3.49-3.44 (m, 2H, $\left.\mathrm{CH}_{2}\right)$, $1.57-1.54\left(\mathrm{~m}, 2 \mathrm{H}, \mathrm{CH}_{2}\right), 1.34-1.15\left(\mathrm{~m}, 26 \mathrm{H}, \mathrm{CH}_{2}\right), 0.87(\mathrm{t}$, $\left.J=6.62 \mathrm{~Hz}, 3 \mathrm{H}, \mathrm{CH}_{3}\right) \cdot{ }^{13} \mathrm{C}$ NMR $\left(\mathrm{CDCl}_{3}\right) \delta: 144.85$, $143.28,132.87,132.12,131.97,131.48,129.08,128.97$, $128.58,128.42,127.90,123.90,122.06,121.25,118.06$, $112.94,111.92,111.21,111.01,32.27,30.07,30.03,29.95$, 29.73, 27.19, 23.01, 14.37. Anal. Calc. for $\mathrm{C}_{36} \mathrm{H}_{45} \mathrm{ONS}_{2}$ : C, 75.66; H, 7.88; O, 2.80; N, 2.45; S, 11.21. FTMS-ESI $(\mathrm{m} / \mathrm{z}):\left[\mathrm{M}^{+}\right]$calc. for $\mathrm{C}_{36} \mathrm{H}_{45} \mathrm{ONS}_{2}, 571.21$.

\section{3,7-Bis(2-furane)-N-alkylphenoxazine (3a-c)}

3,7-Bis(2-furane)-N-alkylphenoxazine (3a-c) Monomer (3) was synthesized according to our previous experience [22, 23] and procedure of obtaining monomers $\mathbf{2 a - c}$, by a coupling condensation of 3,7-dibromo- $N$-alkylphenoxazine $1(1.76 \mathrm{mmol})$ and 2-(-tributylstannyl)furane $(4.06 \mathrm{mmol})$.

Selected data for 3,7-bis(2-furane)-N-butylphenoxazine 3a $\mathrm{Y}=62 \%(0.40 \mathrm{~g})$, brown oil, ${ }^{1} \mathrm{H}$ NMR $\left(\mathrm{CDCl}_{3}\right) \delta$ : $7.69-7.63(\mathrm{~m}, 2 \mathrm{H}$, arom. $\mathrm{H}), 7.47(\mathrm{~d}, J=2.45 \mathrm{~Hz}, 2 \mathrm{H}$, arom. H), 7.44 (d, $J=5.75 \mathrm{~Hz}, 2 \mathrm{H}$, arom. H), 6.92 (d, $J=8.33 \mathrm{~Hz}$, $2 \mathrm{H}$, arom. H), 6.42 (d, J=3.06 Hz, 2H, arom. H), 6.08 (s, $2 \mathrm{H}$, arom. $\mathrm{H}), 3.50-3.45\left(\mathrm{~m}, 2 \mathrm{H}, \mathrm{CH}_{2}\right), 1.61-1.53(\mathrm{~m}, 2 \mathrm{H}$, $\left.\mathrm{CH}_{2}\right), 1.46-1.38\left(\mathrm{~m}, 2 \mathrm{H}, \mathrm{CH}_{2}\right), 1.00(\mathrm{t}, J=7.25 \mathrm{~Hz}, 3 \mathrm{H}$,

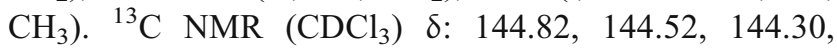
$141.48,133.34,132.07,131.94,131.82,131.79,128.71$, $128.52,128.36,124.95,119.27,118.18,118.02,111.80$, 111.54, 111.04, 110.91, 43.97, 26.76, 20.09, 13.87. Anal. Calc. for $\mathrm{C}_{24} \mathrm{H}_{21} \mathrm{NO}_{3}$ : C, 77.63; H, 5.66; N, 3.77; O, 12.94 . FTMS-ESI (m/z): $\left[\mathrm{M}^{+}\right]$cald. for $\mathrm{C}_{24} \mathrm{H}_{21} \mathrm{NO}_{3:} 371.21$.

Selected data for 3,7-bis(2-furane)-N-nonylphenoxazine 3b $\mathrm{Y}=55 \%(0.41 \mathrm{~g})$, brown oil, ${ }^{1} \mathrm{H}$ NMR $\left(\mathrm{CDCl}_{3}\right) \delta$ : 7.69-7.63 (m, 2H, arom. H), 7.45 (d, $J=4.95 \mathrm{~Hz}, 4 \mathrm{H}$, arom. H), 7.09 (d, $J=2.98 \mathrm{~Hz}, 2 \mathrm{H}$, arom. H), 6.84 (s, 2H, arom. H), $6.42\left(\mathrm{~d}, J=8.72 \mathrm{~Hz}, 2 \mathrm{H}\right.$, arom. H), 3.47-3.42 (m, $\left.2 \mathrm{H}, \mathrm{CH}_{2}\right)$, 1.63-1.58 (m, 2H, $\left.\mathrm{CH}_{2}\right), 1.35-1.26\left(\mathrm{~m}, 12 \mathrm{H}, \mathrm{CH}_{2}\right), 0.86$ (t, $\left.J=6.51 \mathrm{~Hz}, 3 \mathrm{H}, \mathrm{CH}_{3}\right) .{ }^{13} \mathrm{C} \mathrm{NMR}\left(\mathrm{CDCl}_{3}\right) \delta: 144.82,144.52$, $144.30,141.48,133.34,132.07,131.94,131.82,131.79$, $128.71,128.52,128.36,124.95,119.27,118.18,118.02$, $111.80,111.54,111.04,110.91,44.11,31.79,29.50,29.32$, $29.18,26.80,24.87,22.61,14.07$. Anal. Calc. for $\mathrm{C}_{29} \mathrm{H}_{31} \mathrm{NO}_{3}$ : C, 78.91; H, 7.03; N, 3.18; O, 10.88. FTMSESI (m/z): $\left[\mathrm{M}^{+}\right]$calc. for $\mathrm{C}_{29} \mathrm{H}_{31} \mathrm{NO}_{3}, 441.21$.

Selected data for 3,7-bis(2-furane)-N-hexadecylphenoxazine $3 \mathrm{c} \mathrm{Y}=60 \%(0.57 \mathrm{~g})$, yellow crystals, mp. $149^{\circ} \mathrm{C},{ }^{1} \mathrm{H}$ NMR $\left(\mathrm{CDCl}_{3}\right) \delta: 7.67-7.63(\mathrm{~m}, 2 \mathrm{H}$, arom. $\mathrm{H}), 7.48(\mathrm{~d}, J=$ $9.91 \mathrm{~Hz}, 4 \mathrm{H}$, arom. H), 7.46 (d, $J=5.03 \mathrm{~Hz}, 2 \mathrm{H}$, arom. H),
7.30 (s, 2H, arom. H), 6.41 (d, $J=4.62 \mathrm{~Hz}, 2 \mathrm{H}$, arom. H), 3.49-3.43 (m, 2H, $\left.\mathrm{CH}_{2}\right), 1.86-1.79\left(\mathrm{~m}, 2 \mathrm{H}, \mathrm{CH}_{2}\right), 1.77-$ $1.71\left(\mathrm{~m}, 2 \mathrm{H}, \mathrm{CH}_{2}\right), 1.41-1.23\left(\mathrm{~m}, 24 \mathrm{H}, \mathrm{CH}_{2}\right), 0.88(\mathrm{t}, J=$ $\left.8.08 \mathrm{~Hz}, 3 \mathrm{H}, \mathrm{CH}_{3}\right) .{ }^{13} \mathrm{C} \mathrm{NMR}\left(\mathrm{CDCl}_{3}\right) \delta: 144.88,143.31$, $136.47,132.07,131.93,131.43,129.04,128.91,128.58$, $128.35,127.89,123.86,122.04,121.24,118.18,118.01$, $112.94,111.89,111.23,111.04,44.19,31.79,29.66,29.51$, $29.33,29.19,29.18,27.83,27.10,26.85,26.31,24.91$, 22.61, 17.58, 14.06, 13.56. Anal. Calc. for $\mathrm{C}_{36} \mathrm{H}_{45} \mathrm{NO}_{3}: \mathrm{C}$, 80.15; H, 8.35; N, 2.60; O, 8.90. FTMS-ESI (m/z): $\left[\mathrm{M}^{+}\right]$ calc. for $\mathrm{C}_{36} \mathrm{H}_{45} \mathrm{NO}_{3}, 539.21$.

\section{3,7-Bis(2-pyridine)-N-alkylphenoxazine (4a-c)}

3,7-Bis(2-pyridin)-N-alkylphenoxazine (4a-c) Monomer (4) as well as $\mathbf{2}$ and $\mathbf{3}$ was obtained according to our previous experience $[22,23]$ by a Stille coupling reaction of 3 , 7-dibromo- $N$-alkylphenoxazine $1(2.52 \mathrm{mmol})$ with 2 (-tributylstannyl)pyridine $(5.80 \mathrm{mmol})$.

Selected data for 3,7-bis(2-pyridin)-N-butylphenoxazine 4a $\mathrm{Y}=60 \%$ (0.59 g), dark red oil, ${ }^{1} \mathrm{H}$ NMR $\left(\mathrm{CDCl}_{3}\right) \delta: 8.54$ (d, $J=4.68 \mathrm{~Hz}, 2 \mathrm{H}$, arom. H), 7.57-7.38 (m, 6H, arom. H), 7.27 (s, $2 \mathrm{H}$, arom. H), 7.05-7.00 (m, 2H, arom. H), $6.42(\mathrm{~d}$, $J=8.40 \mathrm{~Hz}, 2 \mathrm{H}$, arom. H), 3.40-3.37 (m, $\left.2 \mathrm{H}, \mathrm{CH}_{2}\right), 1.56$ $1.53\left(\mathrm{~m}, 2 \mathrm{H}, \mathrm{CH}_{2}\right), 1.38-1.27\left(\mathrm{~m}, 2 \mathrm{H}, \mathrm{CH}_{2}\right), 0.91(\mathrm{t}, J=$ $\left.7.12 \mathrm{~Hz}, \mathrm{CH}_{3}\right) .{ }^{13} \mathrm{C}$ NMR $\left(\mathrm{CDCl}_{3}\right) \delta: 155.96,149.30,144.94$, $136.50,133.44,132.11,122.13,121.32,119.15,113.51$, $111.34,43.68,27.11,20.05,13.86$. Anal. Calc. for $\mathrm{C}_{26} \mathrm{H}_{23} \mathrm{NO}_{3}$ : C, 79.39; H, 5.85; N, 10.69; O, 4.07. FTMSESI (m/z): [M $\left.\mathrm{M}^{+}\right]$calc. for $\mathrm{C}_{26} \mathrm{H}_{23} \mathrm{NO}_{3}, 393.01$, found, 393.20 .

Selected data for 3,7-bis(2-pyridin)-N-nonylphenoxazine 4b $\mathrm{Y}=54 \%(0.21 \mathrm{~g})$, dark red oil, ${ }^{1} \mathrm{H}$ NMR $\left(\mathrm{CDCl}_{3}\right)$ $\delta: 8.60$ (d, $J=2.83 \mathrm{~Hz}, 2 \mathrm{H}$, arom. H), 7.70-7.64 (m, $2 \mathrm{H}$, arom. H), 7.60-7.57 (m, 2H, arom. H), 7.48 (dd, $J=$ $2.07 \mathrm{~Hz}, J=2.06 \mathrm{~Hz}, 2 \mathrm{H}$, arom. H), 7.31 (s, $J=2.06 \mathrm{~Hz}, 2 \mathrm{H}$, arom. H), 7.16-7.11 (m, 2H, arom. H), 6.55 (d, $J=8.44 \mathrm{~Hz}$, $2 \mathrm{H}$, arom. H), 3.57-3.51 (m, 2H, $\left.\mathrm{CH}_{2}\right), 1.75-1.63(\mathrm{~m}, 2 \mathrm{H}$, $\left.\mathrm{CH}_{2}\right), 1.39-1.24\left(\mathrm{~m}, 12 \mathrm{H}, \mathrm{CH}_{2}\right), 0.88(\mathrm{t}, J=7.94 \mathrm{~Hz}, 3 \mathrm{H}$,

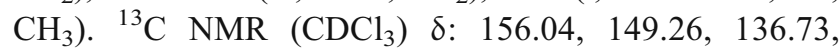
$133.64,132.08,122.29,121.41,119.35,113.63,111.44$, $44.10,31.81,29.53,29.37,29.21,26.88,25.04,22.63$, 14.07. Anal. Calc. for $\mathrm{C}_{31} \mathrm{H}_{33} \mathrm{NO}_{3}: \mathrm{C}, 80.35 ; \mathrm{H}, 7.13 ; \mathrm{N}$, 9.07; O, 3.45. FTMS-ESI (m/z): $\left[\mathrm{M}^{+}\right]$calc. for $\mathrm{C}_{31} \mathrm{H}_{33} \mathrm{NO}_{3}$, 463.21, found, 463.30 .

Selected data for 3,7-bis(2-pyridin)-N-hexadecylphenoxazine $4 \mathrm{c} \mathrm{Y}=47 \%(0.20 \mathrm{~g})$, dark red crystalsl mp. $76^{\circ} \mathrm{C},{ }^{1} \mathrm{H}$ NMR $\left(\mathrm{CDCl}_{3}\right) \delta: 8.61(\mathrm{~d}, J=4.73 \mathrm{~Hz}, 2 \mathrm{H}$, arom. H), 7.70- 
7.46 (m, 6H, arom. H), 7.31 (s, 2H, arom. H), 7.15-7.11 (m, $2 \mathrm{H}$, arom. H), 6.55 (d, $J=8.43 \mathrm{~Hz}, 2 \mathrm{H}$, arom. H), 3.56$3.51\left(\mathrm{~m}, 2 \mathrm{H}, \mathrm{CH}_{2}\right), 1.39-1.35\left(\mathrm{~m}, 28 \mathrm{H}, \mathrm{CH}_{2}\right), 0.86(\mathrm{t}, J=$ $\left.7.05 \mathrm{~Hz}, 3 \mathrm{H}, \mathrm{CH}_{3}\right) .{ }^{13} \mathrm{C} \mathrm{NMR}\left(\mathrm{CDCl}_{3}\right) \delta: 156.15,149.37$, $145.07,136.58,133.61,132.26,122.23,121.39,119.29$, 113.64, 111.42, 76.98, 44.10, 31.89, 29.61, 29.35, 26.88, 25.05, 22.65. Anal. Calc. for $\mathrm{C}_{38} \mathrm{H}_{47} \mathrm{NO}_{3}: \mathrm{C}, 81.28 ; \mathrm{H}$, 8.38; N, 7.49; O, 2.85. HRMS-ESI $(\mathrm{m} / \mathrm{z}):\left[\mathrm{M}^{+}\right]$calc. for $\mathrm{C}_{38} \mathrm{H}_{47} \mathrm{NO}_{3}$, 561.01, found, 561.40.

Absorption and fluorescence spectra in dilute solutions

UV-vis absorption spectra were recorded on UV-VIS HP $8452 \mathrm{~A}$ diode array spectrophotometer in either 1 or $4 \mathrm{~cm}$ quartz cuvettes depending on the sample concentration $\left(10^{-4}-10^{-6} \mathrm{moldm}^{-1}\right)$. Emission spectra were measured at $295 \mathrm{~K}$ in $1 \mathrm{~cm}$ long-neck sealed quartz cuvettes using $90^{\circ}$ geometry on Hitachi F - 2500 fluorescence spectrophotometer. All solutions were purged with $\mathrm{N}_{2}$ for 20 min prior measurement. All emission spectra were corrected using correction data obtained with rhodamine and methylene blue as quantum counters for wavelength out to $720 \mathrm{~nm}$, beyond which the response was estimated from the manufacturer's photomultiplier response data.

Cyclic voltammetry

Cyclic voltammetry (CV) studies were performed using an Ecochemie AUTOLAB potentiostat - galvanostat model PGSTAT20 driven by a computer. Samples were dissolved in acetonitrile $\left(\mathrm{CH}_{3} \mathrm{CN}\right.$ for DNA synthesis and peptides), water $<10 \mathrm{ppm}$, POCh, Gliwice, Poland) with $0.1 \mathrm{M}$ tetrabutylammonium tetrafluoroborate $\mathrm{Bu}_{4} \mathrm{NBF}_{4}$ (Janssen Chimica, $99 \%$ ) in acetonitrile as the supporting electrolyte. Solutions were purged with nitrogen gas prior to each scan. A three electrode system was employed using a platinum working and auxiliary electrode. The SCE was served as a reference electrode. The scan rate was $50 \mathrm{mVs}^{-1}$. Results were analysed using GPES program (General Purpose Electrochemical System). Cyclic voltammetry (CV) of electrodeposited film was taken in monomer-free solutions of the same supporting electrolyte as used for polymerization. The voltamograms were referenced to a ferrocene-ferrocenium couple as the standard $\left(E^{o}=0.42 v s\right.$. SCE $)$.

Formation of Langmuir and Langmuir - Blodgett films

Langmuir monomolecular films of desired composition were spread from $\mathrm{CHCl}_{3}$ solution (concentration of solutions were maintained to ca. $1 \mathrm{mg} / \mathrm{ml}$ ) on high purity water $\left(\sigma<10^{-5} \mathrm{~S} / \mathrm{m}\right)$ at $296 \mathrm{~K}$. The compression rates used in experiments ranged between 10 and $20 \mathrm{~mm} / \mathrm{min}$, depending on the rigidity of the films. Langmuir - Blodgett deposition was carried out with a KSV System 5000 LB through at the surface pressure of around $25 \mathrm{mN} / \mathrm{m}$. Monomelecular films built of 3,7-bis(thiophene)- $\mathrm{N}$ nonylphenoxazine (2b) were prepared by means of vertical dipping of the substrate. LB films were deposited at the velocity lower than the draining rate of film of carboxylic acids i. e. $1.3 \mathrm{~mm} / \mathrm{min}$. After deposition films were stored in vacuum desiccator prior to use. AFM studies of $\mathbf{2 b}$ LB films were carried out using a AFM Dimension V Veeco.

\section{Results and discussion}

\section{Synthesis}

We show that conjugated semiconductors containing the phenoxazine ring have rather low oxidation potentials with some electrochemical reversibility.

The type of condensation, estimated by us as a synthetic procedure (Stille type), has been utilized for the preparation of variety of conjugated aromatic compounds for use in organic light emitting diodes, polymer LEDs and nonlinear optical materials [24]. The cross-coupling reaction of dibromoheterocycle and 2-tributylstannylarylenes catalyzed by palladium phosphine complex is found to provide a efficient, convenient route to conducting compounds. The Stille-type coupling is carried out usually in dry toluene, using palladium compound as catalyst under vigorous stirring at reflux for $24 \mathrm{~h}$. Stille coupling, as well as Suzuki method is also used for obtaining branched or hyperbranched sterically crowded heterocyclic structures. Phenoxaziones and phenothiazines because of their nonplanar structure (butterfly like) are investigated as optical, electroactive material. Phenoxazine based conjugated system appears in literature as modern optoelectronic systems but not so often as well known phenothiazine blocks $[15,16]$.

The synthetic route to the phenoxazine based monomers is outlined in Scheme 1. The reaction was run in a way to provide a systematic variation of the phenoxazine derivatives. The monomer 3,7-dibromo- $N$-alkylphenoxazine (1) was synthesized according modified procedure reported earlier [13, 20-23], in two steps from the starting phenoxazine with high yield ( $70 \%)$. The monomers $\mathbf{2 - 4}$, 3,7-bis(aryl)- $N$-alkylphenoxazines, were prepared (from compound 1) by palladium-catalyzed Stille coupling with a average yield of $\sim 60 \%$.

All the synthesized products were soluble in organic solvents such as chloroform, toluene, and tetrahydrofuran (THF). The molecular structures of the monomers were verified by NMR, MS and UV-VIS spectra. 
Scheme 1 Synthetic setup for $\mathrm{N}$-alkyl-bis(arylene)phenoxazines

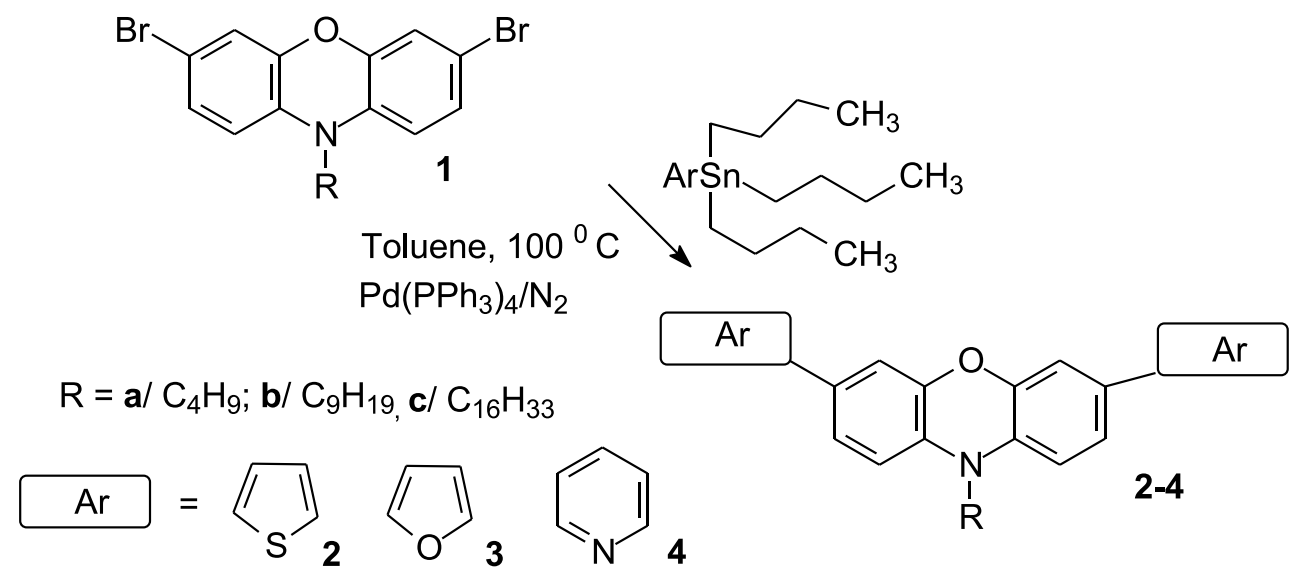

Spectroscopic properties

Phenoxazines usually have high luminescence quantum yields and are known as efficient laser dyes. Because of phenoxazine emission's maxima are close to $400 \mathrm{~nm}$, polymers or other conjugated oligomers containing phenoxazine units could be promising conducting and fluorescent materials.

The selection of a hole- and electron-conducting core is dedicated by the HOMO and LUMO energy levels as well as the charge-carrier mobility.

The photophysical properties of some synthesized compounds $(\mathbf{2} \mathbf{b}, \mathbf{4} \mathbf{b})$ were investigated by UV-VIS and fluorescence spectroscopy in dilute acetonitrile solution $\left(10^{-4}-10^{-6} \mathrm{M}\right)$. The UV-VIS absorption and luminescence properties of hyperbranched blocks were summarized in Figs. 2, 3 and 4 as well as in Table 1. Figure 2 shows the UV-VIS absorption spectra of $\mathbf{2 b}$ and $\mathbf{4 b}$. The 220-320-nm bands in the absorption spectra can be assigned to the $\pi$ $\pi^{*}$ transition whereas the $330-440-\mathrm{nm}$ bands are due to ICT (increasing excited-state dipole moments). The compounds have strong featureless absorption bands with an absorption maximum $\left(\lambda_{\max }\right)$ at $382-400 \mathrm{~nm}$ in dilute solution. The absorption maxima of $\mathbf{2 b}$ and $\mathbf{4 b}$ are similar to values of $\lambda_{\max }$ corresponding to the $\pi-\pi^{*}$ transition in polyphenoxazine backbone [20]. The absorption bands characteristic for phenoxazine ring are localized at about $400 \mathrm{~nm}$.

Compound 2b has two clear peaks with absorption maxima at 265 and $382 \mathrm{~nm}$. The wide and characteristic band with the maximum at $382 \mathrm{~nm}$ is connected with phenoxazine rings but the observed blue-shift suggests that some contribution to the absorption spectrum comes from the thiophene segments.

Similar absorption spectra were found for $4 \mathbf{b}$ (265 and $400 \mathrm{~nm}$ ), but the absorption maxima are red-shifted about $20 \mathrm{~nm}$ in comparison to $\mathbf{2 b}$ (Fig. 2). The red-shifted absorption maxima in these two compounds may be due to the increased electronic delocalization and conformation of bis-pyridine blocks. Summarized, two prominent absorption features were observed in the spectra of both the D-A molecules: a lowest-energy band in the $330-440 \mathrm{~nm}$ range and high-energy bands in the 220-320 nm.

The optical band gap $\left(\mathrm{E}_{\mathrm{gap}}\right)$ derived from the absorption edge of the solution spectra of $\mathbf{2 b}$ and $\mathbf{4 b}$ was in the range of $2.70-2.84 \mathrm{eV}$ (Table 1), the values are differ than it found for polyphenoxazine $(2.44 \mathrm{eV}$ [13]) because of presence of side heterocyclic rings.

The fluorescence emission spectra of phenoxazine derivatives in dilute acetonitrile solutions were recorded at different excitation wavelengths in the range of 374 $390 \mathrm{~nm}$, but the emission values were the same. However, during excitation of the dilute solution of $\mathbf{2 b}$ at 374 the emission was centred at $436 \mathrm{~nm}$ (Fig. 3) whereas $\mathbf{4 b}$, excited at $390 \mathrm{~nm}$ has an emission at $460 \mathrm{~nm}$ (Fig. 4), the bands are of almost comparable intensities, but the fluorescence quantum yields of the compound $\mathbf{2} \mathbf{b}$ is slightly smaller than $\mathbf{4 b}$, which is probably due to the photoinduced intramolecular transfer between two chromophores. On the other hand, it was noticed the similar emission shapes. It may be assumed that emission is connected mainly with

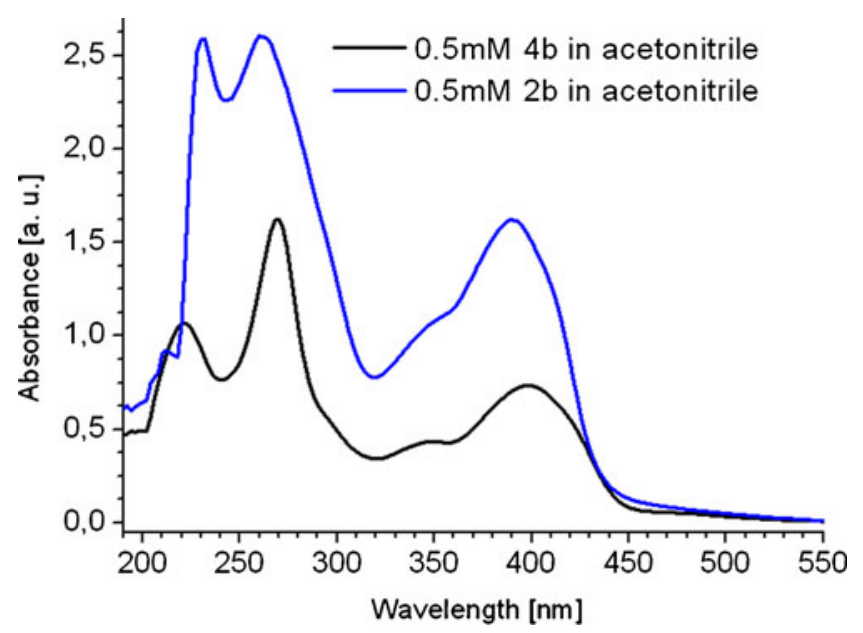

Fig. 2 UV-VIS spectra of diluted $\mathbf{2 b}$ and $\mathbf{4 b}$ in acetonitrile 
Fig. 3 The fluorescence spectra of $1 \mu \mathrm{M}$ solution of $\mathbf{2 b}$ in acetonitrile
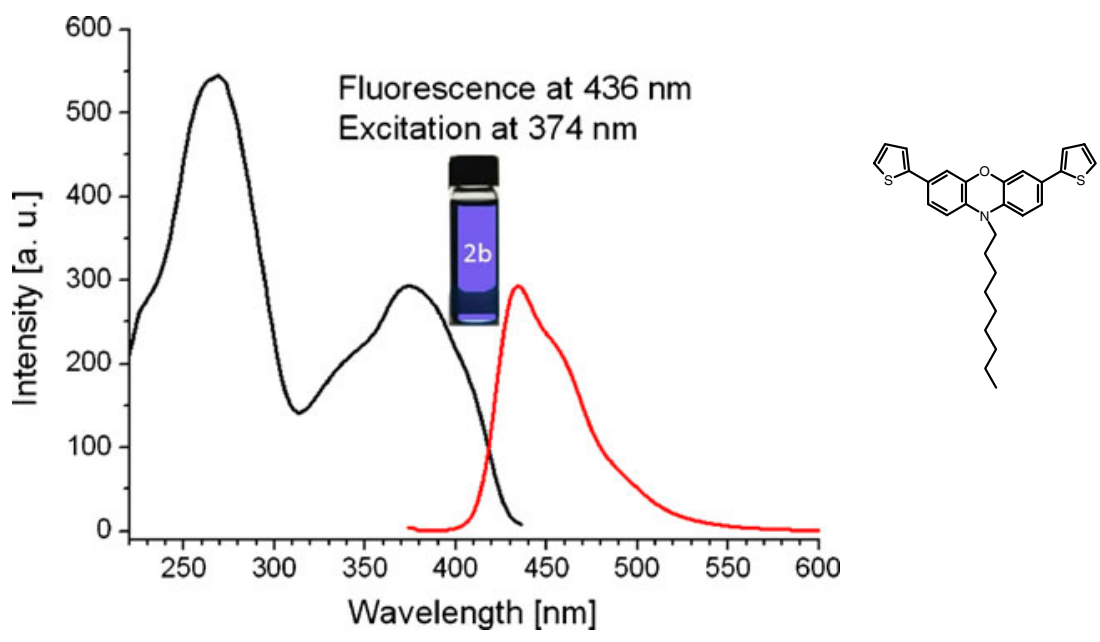

excitation of the phenoxazine ring. Following excitation into the $S_{2}$ band the phenoxazines exhibit $S_{2}->S_{0}$ fluorescence. The $S_{2}->S_{0}$ fluorescence bands of $\mathbf{2 b}$ and 4b are located in the region of $430-480 \mathrm{~nm}$, which is considerably red-shifted to the pure nonylphenoxazine fluorescence, which has a maximum at ca. $450 \mathrm{~nm}$ (not shown). The $S_{2}->S_{0}$ fluorescence band observed for $\mathbf{4 b}$ is also broader than the corresponding emission band of $\mathbf{2} \mathbf{b}$, with full-width-at-half-maxima of ca. 7,000 and $5,000 \mathrm{~cm}^{-1}$ respectively.

The emission spectrum of $\mathbf{4 b}$ dramatically red shifts with increasing electron- accepting strength. Compound $\mathbf{4 b}$ emits a blue color in solution (2b - blue-violet). The obvious reason for the observed red shift is characteristic of donor- $\pi$-acceptor structure, which may induce solvent polar effects on their maximal absorption wavelength. It is also connected with the greater degree of ICT with increasing electron acceptor strength.

Thus, emission colors spanning the entire visible region are obtained from the phenoxazinebased D-A molecules, demonstrating how charge transfer and the resultant ICT fluorescence in a D-A molecule can be effectively manipulated through the electronaccepting strength of the acceptor building block.

\section{Electrochemical properties}

To understand the electronic structures of the phenoxazine derivative molecules, we performed cyclic voltammetry (CVs) measurements.

Experimental results and theoretical calculations suggest that 5 and $5^{\prime}$ (Fig. 1) positions in five-membered heterocyclic ring are characteristic places for electrochemical polymerization [25]. The polymerization leads to copolymer with alternate phenoxazine and biheterocyclic groups (e.g. thiophene) in the main chain.

Cyclic voltammgrams of compounds $(\mathbf{2 b}, \mathbf{4 b})$ in acetonitrile are shown in Figs. 5, 6 and 7. The electronic states (HOMO/LUMO levels) of the polyphenoxazine homopolymer [13] as well as synthesized 3,7-bis(2thiophene/pyridine)- $N$-nonylphenoxazines $(\mathbf{2} \mathbf{b}, \mathbf{4 b}) \mathrm{did}$ not show a reduction wave in the range from -0.5

Fig. 4 The fluorescence spectra of $10 \mu \mathrm{M}$ solution of $\mathbf{4 b}$ in acetonitrile

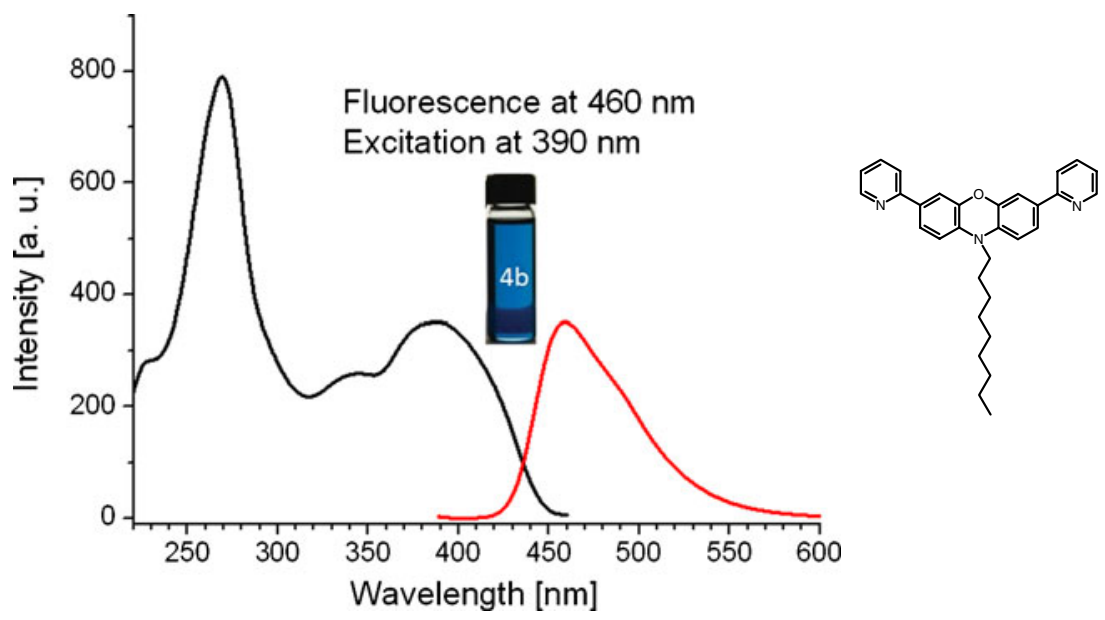


Table 1 Summary of physical properties of phenoxazine derivatives

\begin{tabular}{lcccc}
\hline compound & $\begin{array}{l}\text { in acetonitrile solution } \\
\left(5 \times 10^{-4}-10^{-4} \mathrm{M}\right)\end{array}$ & $\begin{array}{l}\mathrm{E}_{\text {gap }}^{\mathrm{b}} \\
{[\mathrm{eV}]}\end{array}$ & $\begin{array}{l}\mathrm{E}_{\text {gap }}^{\mathrm{c}} \\
{[\mathrm{eV}]}\end{array}$ \\
\cline { 2 - 3 } & $\begin{array}{l}\text { abs } \lambda_{\max } \\
{[\mathrm{nm}]}\end{array}$ & $\begin{array}{l}\text { Em } \lambda_{\max }{ }^{\mathrm{a}} \\
{[\mathrm{nm}]}\end{array}$ & & \\
\hline 2b & 382 & 436 & 3.54 & 2.84 \\
4b & 400 & 460 & 3.43 & 2.70
\end{tabular}

$0.0 \mathrm{~V}$, suggesting a $p$-type semiconducting material in case of polyphenoxazine.

The following discussion is focused on the electrochemical oxidation of bis(aryl)- $N$-alkylphenoxazines, which occurs apparently in several steps and seems to be quite complicated. The CVs of the molecules $\mathbf{2 b}, \mathbf{4 b}$ (Figs. 5, and 6) can be repeatedly scanned many cycles in the range $-0.5-1.4 \mathrm{~V}$ ( $v s \mathrm{SCE}$ ). The monomer $\mathbf{2 b}$ (Fig. 5) as well as 4b (Fig. 6) has rather clear oxidation waves (especially noticeable in case of $\mathbf{2 b}$ ), that are not always reversible, highly reversible is only the first redox system for $\mathbf{2 b}$ and $\mathbf{4 b}$, as evident from the areas and close proximity of the anodic and cathodic peaks.

According to the possibility of obtaining copolymers of the synthesized phenoxazine structures, it is crucial to mention that the homopolymer of phenoxazine [20] has an onset oxidation potential of $0.36 \mathrm{~V}$ ( $v s \mathrm{SCE}$ ), from which was estimated an ionization potential of $4.8 \mathrm{eV}$. The IP values found for phenoxazine copolymers were very similar $\sim 4.7 \mathrm{eV}$ (Table 2). The $4.8 \mathrm{eV}$ IP value for the phenoxazine - thiophene block is hardly less than poly(3-hexylthiophene) $(4.9 \mathrm{eV}$ [13]). These results suggest that the phenoxazine ring is a building block for lowering the IP of conjugated copolymers or oligomers. The reversible electrochemical oxidation and low IP of phenoxazine and

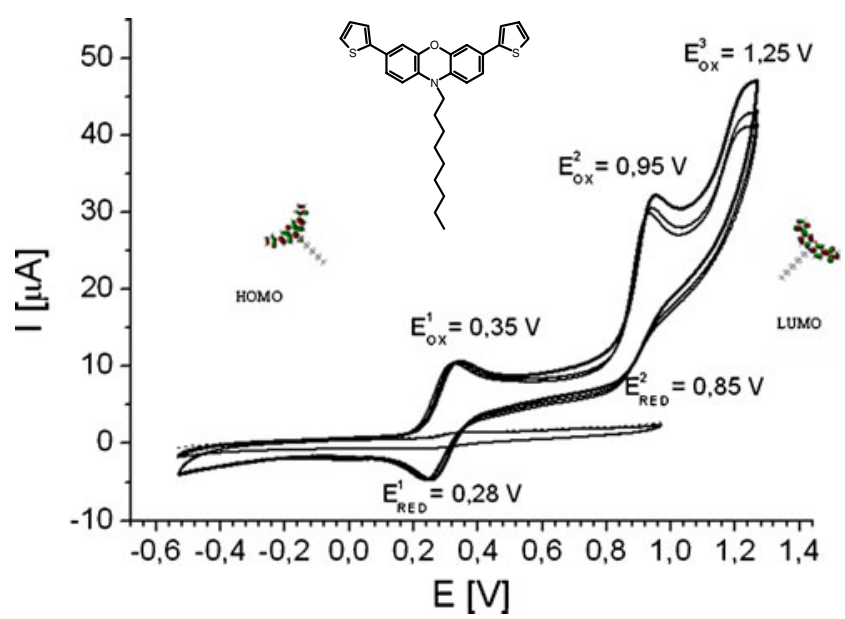

Fig. 5 Cyclic voltammetry of 3,7-bis(2-thiophene)- $N$-nonylphenoxazine $(\mathbf{2 b})$ in $0.1 \mathrm{mM}$ solution of $0.1 \mathrm{M} \mathrm{Bu}_{4} \mathrm{NBF}_{4}$ in acetonitrile. Potential sweep rate $v=50 \mathrm{mV} / \mathrm{s}$

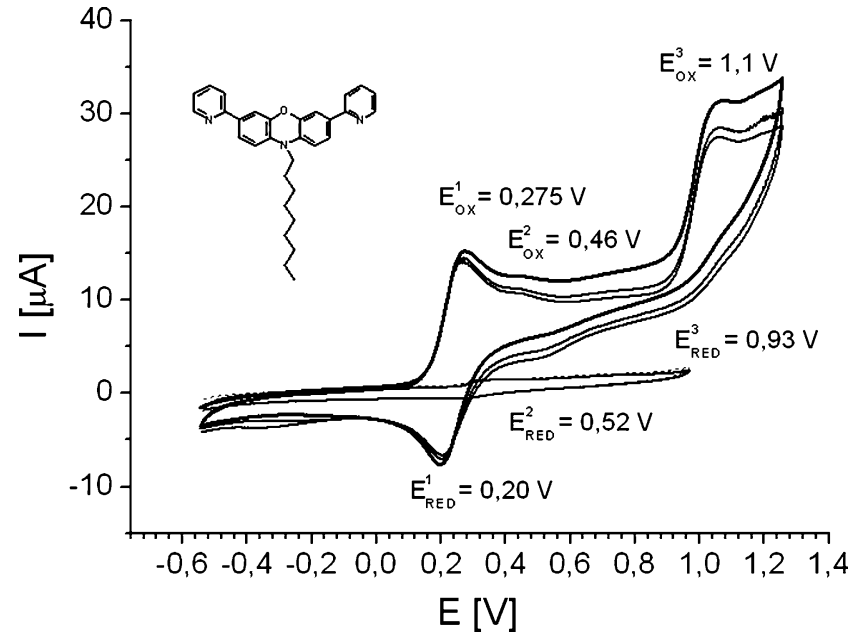

Fig. 6 Cyclic voltammetry of 3,7-bis(2-pyridine)- $N$-nonylphenoxazine $(4 \mathbf{b})$ in $0.1 \mathrm{mM}$ solution of $0.1 \mathrm{M} \mathrm{Bu}_{4} \mathrm{NBF}_{4}$ in acetonitrile. Potential sweep rate $v=50 \mathrm{mV} / \mathrm{s}$

its copolymers suggest the efficient hole injection and transport with regard to gold, which is commonly used as the source and drain electrodes in organic field transistors.

Repetitive scanning of the monomer $\mathbf{2 b}$ solution within the specific potential range results in uniform and coherent film formation on the electrode surface (Fig. 7). The polymeric film formation is evidenced by the successive growth of the current within the $0.2-1.2 \mathrm{~V}$ potential range. Electrochemical polymer films built stable homogeneous layers on PT electrode.

In the case of $\mathbf{2} \mathbf{b}$ molecule despite presence of thiophene rings, in first cycle we do not observe polymerization of radical cation, because this process is connected with dication. Analysis of successive voltammetric cycles allow to claim that during 20 cycles first redox system does not change (Fig. 7) therefore every next cycle displace

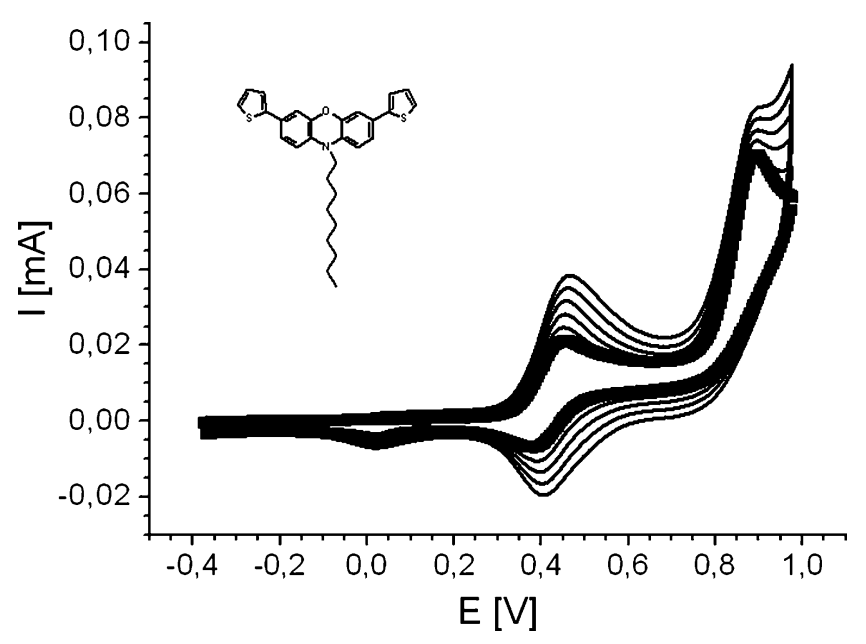

Fig. 7 Cyclic voltammetry of $\mathbf{2 b}$ in $0.1 \mathrm{M}$ solution of $\mathrm{Bu}_{4} \mathrm{NBF}_{4}$ in acetonitrile. Potential sweep rate $v=50 \mathrm{mV} / \mathrm{s} ; 30$ scans 
Table 2 Redox properties of phenoxazine derivatives

\begin{tabular}{lc}
\hline compound & IP $(\mathrm{eV})^{\mathrm{a}}$ \\
\hline $\mathbf{2 b}$ & 4.75 \\
$\mathbf{4 b}$ & 4.68 \\
\hline
\end{tabular}

maximum of first oxidation peak to higher potentials, results in lower first oxidation peak and disappearing proper reduction peak.

Results of CV measurements (Fig. 8) suggest that shape of $\mathrm{CV}$ curves is dependent on thickness of polymer film.

In case of thick polyphenoxazine film we observed total demise of electroactivity phenoxazine radical cation's redox system, whereas there is new oxidation peak in $0.78 \mathrm{~V}$. This type of behaving is connected with structure of the main polymer chain (Fig. 1).

Butterfly like structure of phenoxazine derivative makes difficult delocalization of charge on conjugated chain, in this case electron can not move along polymer backbone. Observed first redox process is at $0.28 \mathrm{~V}$ and is connected with electron transfer between phenoxazines of neighbored polymer chains.

Transfer velocity of electrons depends on distances between phenoxazine mers and decreases with increasing of disorder in main backbones.

Deficiency in polymer order is connected with film thickness, then is observed considerable remission of first redox couple (Fig. 8), connected with phenoxazine units dismissing from electrode surface. As the electrode potential finds enough value to oxidize bithiophenes, positive charge of polymer is also able to free moving along the polymer backbone and between neighbored chains, then polymer behaves as an electroconducting material. Such a situation confirms the phenoxazines oxidize by oxidized bithiophene units.

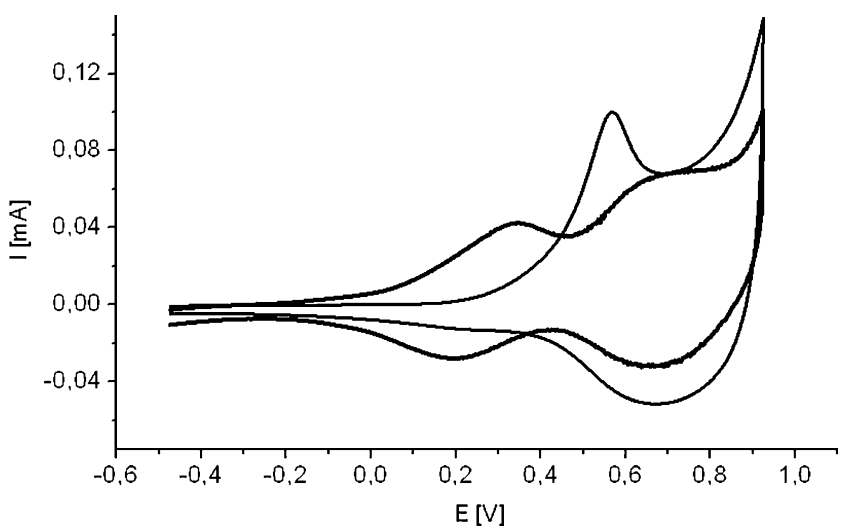

Fig. 8 Cyclic voltammerty of poly-2b film in $0.1 \mathrm{M}$ solution of $\mathrm{Bu}_{4} \mathrm{NBF}_{4}$ in acetonitrile. Potential sweep rate $v=50 \mathrm{mV} / \mathrm{s}$. 1 -film synthesized in 10 voltammetric cycles, 2-film synthesized in 30 voltammetric cycles. Both cycles were normalized according maximum of second redox system peak

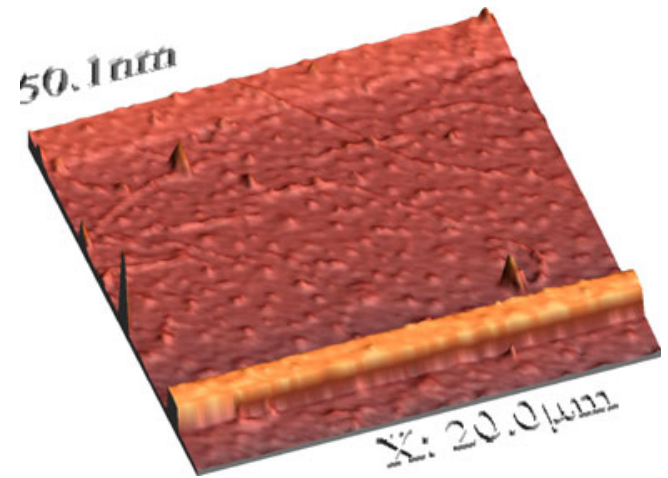

Fig. 9 AFM image of active layer of $\mathbf{2 b}$ LB film (20 layers) on glass slide, top view

\section{Characteristic of thin Langmuir-Blodgett films}

The technique of Langmuir-Blodgett was also employed to obtain thin molecular film of bis(thiophene)phenoxazines. In this connection, phenoxazine derivative - $N$-nonyl-3,7-bis(2thiophene)phenoxazine, dissolved in organic solvents (chloroform) was spread on the water. Then organic layers were deposited by LB technique onto a set of eight interdigital, buried $\mathrm{Au}$ electrodes photolithographically fixed on $\mathrm{SiO}_{2}$ thermally coated silicon substrates or on silicon substrates.

Langmuir monomolecular films of phenoxazine derivatives $\mathbf{2 b}$ - was spread from $\mathrm{CHCl}_{3}$ solution on high purity water. LB deposition was carried out with a KSV System $5000 \mathrm{LB}$ through at a surface pressure of around $25 \mathrm{mN} / \mathrm{m}$.

The deposition processes were carried out at room temperature as well as conductivity measurements. The transference of LB film was Y - type in first deposition and $\mathrm{Z}$ - type in following ones. The relationship between absorbance and number of layers and constant transfer ratio during the deposition indicated a constant architecture of LB film layers.

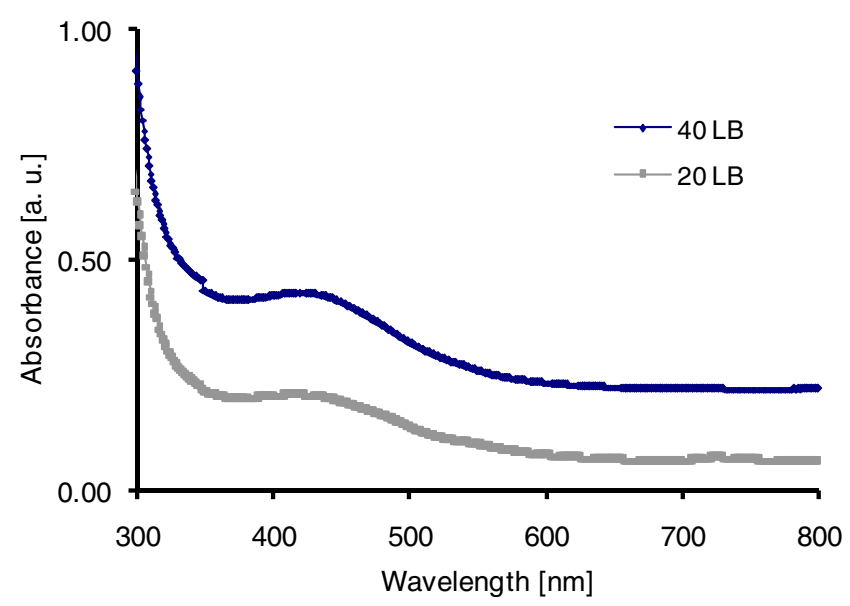

Fig. 10 Normalized optical absorption spectra of phenoxazine derivative $\mathbf{2 b}$ as thin films on silica substrates 


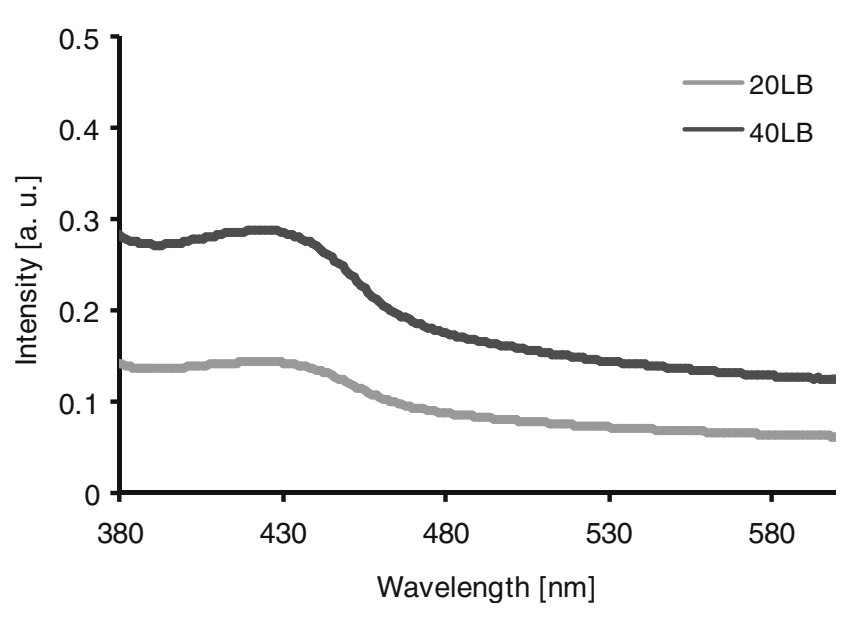

Fig. 11 Normalized fluorescence spectra of phenoxazine derivative 2b as thin films on silica substrates, Ex. $374 \mathrm{~nm}$

The morphology of LB layers of phenoxazine derivative was examined using atomic force microscopy (AFM). Figure 9 shows the tapping-mode AFM images of Langmuir - Blodgett layers on silicon slides. The homogeneous films average roughness is not very high for an LB film. The roughness of $\mathbf{2} \mathbf{b}$ was measured as $4.9 \mathrm{~nm}$, it is probably due to reorganization of big molecule of $\mathbf{2} \mathbf{b}$. In fact, a rather high degree of homogeneity is observed for the film, layers are rather compact and well-organized.

The normalized optical absorption spectra of the phenoxazine conjugated derivative $\mathbf{2} \mathbf{b}$ as thin films are shown in Fig. 10. The absorption spectra of thin films of these compounds are generally similar in shape to those in dilute solutions. The lowest energy $\pi-\pi^{*}$ transition is centered at $440 \mathrm{~nm}$ while an additional higher energy band is found at $303 \mathbf{n m}$. The absorption maximum of $\mathbf{2 b}$ is clearly redshifted to $440 \mathrm{~nm}$ compared to dilute solution (382 $\mathrm{nm})$. The red-shifted absorption maximum in case of thin LB film of $\mathbf{2 b}$ is due to a more planar conformation in the solid state. The similarity in terms of spectral shapes between the thin film absorption spectra and dilute solution spectra suggests comparable ground-state electronic structures of compound with no significant change in conformation in the condensed state.

Figure 11 shows the fluorescence emission spectra of the thin LB film of $\mathbf{2} \mathbf{b}$. In the solid state, the emission maxima of many conjugated polymers are usually red-shifted by 13-23 nm relative to those in solution [13]. The spectrum of LB film of $\mathbf{2 b}$ shows the emission peak at $448 \mathrm{~nm}$.

An investigations of the electrical conductivity of LB films consisting twenty monolayers of 3,7-bis(2-thiophene)- $N$-nonyl -phenoxazine (2b) a potential precursors of the new conducting polymers were carried out with Keithley 614 electrometer.

Figure 12 shows typical $I-V$ curves of fabricated 20layers LB films at room temperature. The $I-V$ curves are asymmetric and non-linear. The forward currents follow approximately an exponential trend. This $I-V$ behaviour is connected with typical semiconducting properties.

The current flowing through as-deposited films in most cases ranged between $610^{-6} \mathrm{~A}$ and $1.210^{-7} \mathrm{~A}$ at room temperatures, furthermore the current apparently increasing during exposure on white light. There was found also the estimated conductivity, $\sigma=1.410^{-6} \mathrm{~S} / \mathrm{m}$.

Therefore, these results indicate that the obtained films behave as semiconductor.

\section{Conclusions}

In summary, we have demonstrated a synthesis of series new phenoxazine-based molecules. The main purposes of investigation were also electrochemical and photophysical properties of designed electro-donor/acceptor tricyclic units. The obtained, amphiphilic phenoxazine structures seemed to be a valuable tool to allow both fabrication of multilayer conducting devices with modest carrier mobility, and some materials with optical properties.

The synthesized molecules opens a broad window of transmission in the blue region of the visible spectrum. Tricycles phenoxazine molecules exhibit rather reversible
Fig. 12 The current-voltage characteristics of 20 layer LB film built of 3,7-bis(2thiophene)- $N$-nonylphenoxazine (2b)

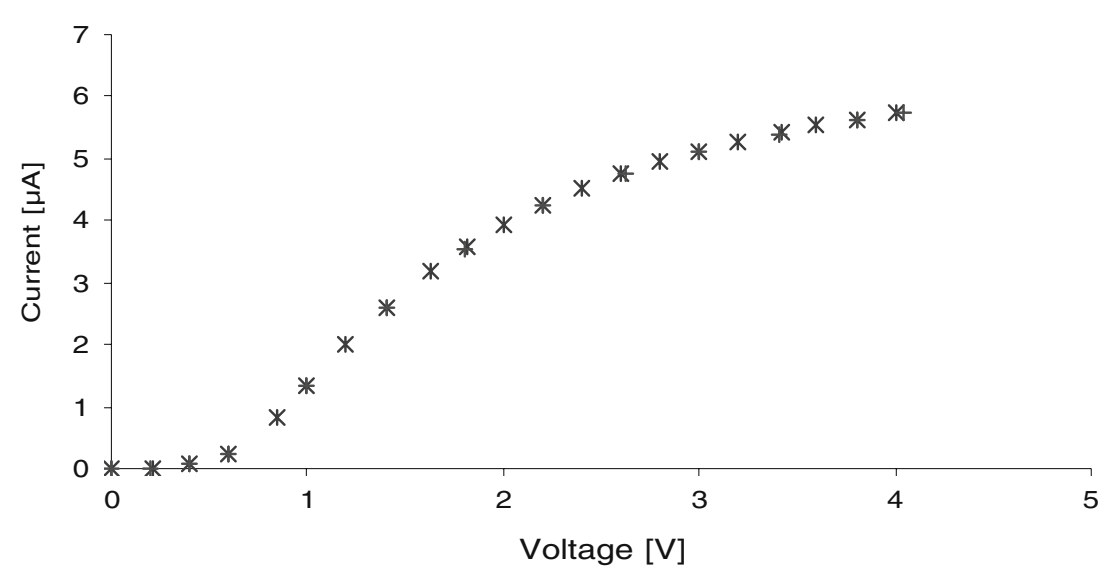


electrochemical oxidation and reduction, indicating ambipolar redox properties that could facilitate efficient hole/ electron injection, transport, and charge recombination. The phenoxazine-based molecules have low ionization potentials $(4.68-4.75 \mathrm{eV})$ characteristic for conducting structures. Overall, these studies offer a viable approach to semiconducting material with high stability and usability.

Acknowledgements Financial support from the Wroclaw University of Technology and Polish Ministry of Science and Higher Education Grant No. NN 204244934 authors are gratefully acknowledged. The AFM data was visualized by WSxM software (Horcas I., Fernandez R., Gomez - Rodriguez J. M., Colchero J., Gomez - Herrero J., Baro A. M., Rev. Sci. Instrum., 78 (2007), 013705).

Open Access This article is distributed under the terms of the Creative Commons Attribution Noncommercial License which permits any noncommercial use, distribution, and reproduction in any medium, provided the original author(s) and source are credited.

\section{References}

1. Newman CR, Frisbie CD, da Silva Filho DA, Bredas JL, Ewbank PC, Mann KR (2004) Introduction to organic thin film transistors and design of n-channel organic semiconductors. Chem Mater $16: 4436-4451$

2. Kline RJ, McGehee MD, Kadnikova EN, Liu J, Frechet JMJ, Toney MF (2005) Dependence of regioregular poly(3-hexylthiophene) film morphology and field-effect mobility on molecular weight. Macromolecules 38:3312-3319

3. Babel A, Jenekhe SA (2004) Morphology and field-effect mobility of charge carriers in binary blends of poly(3-hexylthiophene) with poly [2-methoxy-5-(2-ethylhexoxy)-1, 4-phenylenevinylene] and polystyrene. Macromolecules 37:9835-9840

4. Coakley KM, McGehee MD (2004) Conjugated polymer photovoltaic cells. Chem Mater 16:4533-4542

5. Chang CC, Pai CL, Chen WC, Jenekhe SA (2005) Spin coating of conjugated polymers for electronic and optoelectronic applications. Thin Solid Films 479:254-260

6. Tan Z, Zhou E, Yang Y, He Y, Yang C, Li Y (2007) Synthesis, characterization and photovoltaic properties of thiophene copolymers containing conjugated side-chain. Eur Polym J 43:855861

7. Zhang S, He C, Liu Y, Zhan X, Chen J (2009) Synthesis of a soluble conjugated copolymer based on dialkyl-substituted dithienothiophene and its application in photovoltaic cells. Polymer 50:3595-3599

8. Argun AA, Aubert PH, Thompson BC, Schwendeman I, Gaupp CL, Hwang J, Pinto NJ, Tanner DB, MacDiarmid AG, Reynolds JR (2004) Multicolored electrochromism in polymers: structures and devices. Chem Mater 16:4401-4412
9. Uner E, Beaujuge PM, Ellinger S, Jung JH, Reynolds JR (2009) Black to transmissive switching in a pseudo three-electrode electrochromic device. Chem Mater 21:5145-5153

10. Kulkarni AP, Tonzola CJ, Babel A, Jenekhe SA (2004) Electron transport materials for organic light-emitting diodes. Chem Mater $16: 4556-4573$

11. Zhu Y, Kulkarni AP, Jenekhe SA (2005) Phenoxazine-based emissive donor-acceptor materials for efficient organic lightemitting diodes. Chem Mater 17:5225-5227

12. Okamoto T, Kozaki M, Doe M, Uchida M, Wang G, Okada K (2005) 1, 4-Benzoxazino[2, 3-b]phenoxazine and its sulfur analogues: synthesis, properties, and application to organic lightemitting diodes. Chem Mater 17:5504-5511

13. Zhu Y, Babel A, Jenekhe SA (2005) Phenoxazine-based conjugated polymers: a new class of organic semiconductors for fieldeffect transistors. Macromolecules 38:7983-7991

14. Ito Y, Shimada T, Ha J, Vacha M, Sato H (2006) Synthesis and characterization of a novel electroluminescent polymer based on a phenoxazine derivative. J Polym Sci A: Polym Chem 44:4338-4345

15. Doskocz J, Sołoducho J, Cabaj J, Łapkowki M, Plewa S, Palewska K (2007) Novel approach for synthesis, electroconductivity, LB moieties of Phenothiazine based derivatives. Electroanalysis 19:1394-1401

16. Yang L, Feng J-K, Ren A-M (2005) Theoretical study on electronic structure and optical properties of phenothiazine-containing conjugated oligomers and polymers. J Org Chem 70(15):5987-5996

17. Yuanfu P, Otake M, Vacha M, Sato H (2007) Synthesis and characterization of a novel electroluminescent polymer based on phenoxazine and fluorene derivatives. React Funct Polym 67:1211-1217

18. Idzik K, Sołoducho J, Łapkowski M, Golba S, Development of structural characterization and physicochemical behaviour of triphenylamine blocks. Electrochimica Acta, 53: 5665-5669

19. Łapkowski M, Plewa S, Stolarczyk A, Doskocz J, Sołoducho J, Cabaj J, Bartoszek M, Sułkowski WW (2008) Electrochemical synthesis of polymers with alternate phenothiazine and bithiophene units. Electrochim Acta 53:2545-2552

20. Kong X, Kulkarni AP, Jenekhe SA (2003) Phenothiazine-based conjugated polymers: synthesis, electrochemistry, and lightemitting properties. Macromolecules 36:8992-8999

21. Bohnen H, Herwig J, Arnold J, Hoff D, Sturm S, Van Leeuwen PWNM, Bronger R, Stelzer O (2003) Novel diphosphines and a method for their production. Ger. Offen. DE 10,225,283, Chem. Abstr. 2003, 140, 16815

22. Cabaj J, Idzik K, Sołoducho J, Chyla A (2006) Development in synthesis and electrochemical properties of thienyl derivatives of carbazole. Tetrahedron 62:758-764

23. Idzik K, Sołoducho J, Cabaj J, Mosiądz M, Łapkowski M, Golba S (2008) The novel aspects of convenient synthesis and electroproperties of derivatives based on diphenylamine. Helv Chim Acta 91:618-627

24. Corbet J-P, Mignani G (2006) Selected patented cross-coupling reaction technologies. Chem Rev 106:2651-2710

25. Doskocz J, Doskocz M, Roszak S, Sołoducho J, Leszczyński J (2006) Theoretical studies of symmetric five-membered heterocycle derivatives of carbazole and fluorene: precursors of conducting polymers. J Phys Chem A 110:13989-13994 